\title{
Framingham Heart Study I00K project: genome-wide associations for cardiovascular disease outcomes
}

\author{
Martin G Larson*1,2, Larry D Atwood 1,3, Emelia J Benjamin 1,3,4, \\ L Adrienne Cupples ${ }^{1,5}$, Ralph B D'Agostino Sr1,2, Caroline S Fox ${ }^{1}$, \\ Diddahally R Govindaraju ${ }^{1,3}$, Chao-Yu Guo ${ }^{1,3}$, Nancy L Heard-Costa1,3, Shih- \\ Jen Hwang1, Joanne M Murabito ${ }^{1,6}$, Christopher Newton-Cheh ${ }^{1,7,8}$, \\ Christopher J O'Donnell1,7, Sudha Seshadri1,3, Ramachandran S Vasan1,3,4, \\ Thomas J Wang 1,7 , Philip A Wolf1,3 and Daniel Levy ${ }^{1}$
}

\begin{abstract}
Address: ${ }^{1}$ The National Heart, Lung, and Blood Institute's Framingham Heart Study, Framingham, MA, USA, ${ }^{2}$ Department of Mathematics and Statistics, Boston University, Boston, MA, USA, ${ }^{3}$ Boston University School of Medicine, Boston, MA, USA, ${ }^{4}$ Whitaker Cardiovascular Institute, Boston University School of Medicine, Boston, MA, USA, ${ }^{5}$ Department of Biostatistics, Boston University School of Public Health, Boston, MA, USA, ${ }^{6}$ Section of General Internal Medicine, Boston University School of Medicine, Boston, MA, USA, ${ }^{7}$ Cardiology Division, Massachusetts General Hospital, Harvard Medical School, Boston, MA, USA and ${ }^{8}$ Broad Institute of Harvard and MIT, Cambridge, MA, USA

Email: Martin G Larson* - mlarson@bu.edu; Larry D Atwood - lda@bu.edu; Emelia J Benjamin - emelia@bu.edu; L Adrienne Cupples - adrienne@bu.edu; Ralph B D'Agostino - ralph@bu.edu; Caroline S Fox - foxca@nhlbi.nih.gov;

Diddahally R Govindaraju - drgraju@bu.edu; Chao-Yu Guo - Chao-Yu.Guo@childrens.harvard.edu; Nancy L Heard-Costa - nheard@bu.edu; Shih-Jen Hwang - hwangs2@nhlbi.nih.gov; Joanne M Murabito - murabito@bu.edu; Christopher Newton-Cheh - cnewtoncheh@partners.org; Christopher J O'Donnell - odonnellc@nhlbi.nih.gov; Sudha Seshadri - suseshad@bu.edu; Ramachandran S Vasan - vasan@bu.edu; Thomas J Wang - tjwang@partners.org; Philip A Wolf - pawolf@bu.edu; Daniel Levy - levyd@nhlbi.nih.gov

* Corresponding author
\end{abstract}

\section{Published: 19 September 2007}

BMC Medical Genetics 2007, 8(Suppl I):S5 doi:10.1 186/147I-2350-8-SI-S5

This article is available from: http://www.biomedcentral.com/I47I-2350/8/SI/S5

(C) 2007 Larson et al; licensee BioMed Central Ltd.

This is an open access article distributed under the terms of the Creative Commons Attribution License (http://creativecommons.org/licenses/by/2.0), which permits unrestricted use, distribution, and reproduction in any medium, provided the original work is properly cited.

\begin{abstract}
Background: Cardiovascular disease (CVD) and its most common manifestations - including coronary heart disease (CHD), stroke, heart failure (HF), and atrial fibrillation (AF) - are major causes of morbidity and mortality. In many industrialized countries, cardiovascular disease (CVD) claims more lives each year than any other disease. Heart disease and stroke are the first and third leading causes of death in the United States. Prior investigations have reported several single gene variants associated with $\mathrm{CHD}$, stroke, $\mathrm{HF}$, and $\mathrm{AF}$. We report a community-based genome-wide association study of major CVD outcomes.
\end{abstract}

Methods: In 1345 Framingham Heart Study participants from the largest 310 pedigrees (54\% women, mean age 33 years at entry), we analyzed associations of 70,987 qualifying SNPs (Affymetrix I00K GeneChip) to four major CVD outcomes: major atherosclerotic CVD ( $n=142$; myocardial infarction, stroke, CHD death), major CHD ( $n=118$; myocardial infarction, CHD death), AF $(n=151)$, and HF $(n=73)$. Participants free of the condition at entry were included in proportional hazards models. We analyzed model-based deviance residuals using generalized estimating equations to test associations between SNP genotypes and traits in additive genetic models restricted to autosomal SNPs with minor allele frequency $\geq 0.10$, genotype call rate $\geq 0.80$, and Hardy-Weinberg equilibrium $p$-value $\geq 0.00 \mathrm{I}$.

Results: Six associations yielded $p<10^{-5}$. The lowest $p$-values for each CVD trait were as follows: major CVD, rs 499818 , $p=6.6 \times 10^{-6} ;$ major CHD, rs25495I3, $p=9.7 \times 10^{-6} ; \mathrm{AF}, \mathrm{rs} 958546, \mathrm{p}=4.8 \times 10^{-6} ; \mathrm{HF}: \mathrm{rs} 740363, \mathrm{p}=8.8 \times 10^{-6}$. Of note, we found associations of a $13 \mathrm{~Kb}$ region on chromosome 9p2I with major CVD (p I.7 $\left.-1.9 \times 10^{-5}\right)$ and major 
CHD (p $\left.2.5-3.5 \times 10^{-4}\right)$ that confirm associations with CHD in two recently reported genome-wide association studies. Also, rs 0501920 in CNTN5 was associated with AF $\left(p=9.4 \times 10^{-6}\right)$ and HF $\left(p=1.2 \times 10^{-4}\right)$. Complete results for these phenotypes can be found at the dbgap website http://www.ncbi.nlm.nih.gov/projects/gap/cgi-bin/study.cgi?id=phs000007.

Conclusion: No association attained genome-wide significance, but several intriguing findings emerged. Notably, we replicated associations of chromosome 9p2I with major CVD. Additional studies are needed to validate these results. Finding genetic variants associated with CVD may point to novel disease pathways and identify potential targeted preventive therapies.

\section{Background}

Cardiovascular disease (CVD) and its most common manifestations, coronary heart disease (CHD), stroke, heart failure (HF), and atrial fibrillation (AF) are major causes of morbidity and mortality. In many industrialized countries CVD claims more lives each year than any other disease. In the United States, for example, heart disease and stroke are the first and third leading causes of death [1]. At age 40 the lifetime risk of developing CHD is one in two for men and one in three for women [2], the lifetime risk for stroke is one in six for men and one in five for women [3], the lifetime risk for $\mathrm{HF}$ is one in five in men and women [4] and the lifetime risk for $\mathrm{AF}$ is one in four in both sexes [5].

Prior Framingham Heart Study research points to strong familial patterns of CVD, HF, and AF [6-8] and such evidence is consistent with a genetic effect. Several single gene variants associated with $\mathrm{CHD}$ and atherosclerotic CVD have been reported [9-13]. A substantial body of research has also identified a number of genetic variants associated with HF and AF [14,15].

We report results of a genome-wide association study of four CVD outcomes in community-based Framingham Heart Study participants who were enrolled without regard to disease status. Analysis for each specific outcome was restricted to those free of the condition at baseline. We also provide association results for previously reported candidate genes and candidate regions for these CVD outcomes.

\section{Methods \\ Study sample}

In 1948, 5209 men and women from Framingham, Massachusetts, who were between 28 and 62 years of age, were recruited to participate in the Framingham Heart Study [16]. Periodic clinic visits, performed every two years, included a medical history, physical examination focusing on the cardiovascular system, laboratory tests, and electrocardiogram. The offspring cohort of the Framingham Heart Study began in 1971, with the enrollment of 5124 offspring and spouses of offspring of original participants [17]. Repeated examinations of the offspring cohort occurred approximately every 4 years, except for an
8 year interval between their initial and second visit. At each clinic visit, participants gave written informed consent. The consent documents and the examination content were approved by the Institutional Review Board at Boston University Medical Center (Boston, Massachusetts).

\section{Phenotype definition \& methods}

All participants in both cohorts who were free of a specific condition at enrollment were analyzed for onset of that endpoint during follow up through the end of 2004. All suspected CVD events were reviewed and adjudicated by a panel of three Framingham physician investigators after review of all available Framingham Heart Study examination records, hospitalization records, and physician notes, using previously published criteria [18].

For these analyses, we considered four groups of events: major CHD events included recognized myocardial infarction, coronary insufficiency, and death due to CHD; major atherosclerotic CVD events included major CHD plus atherothrombotic stroke; the remaining groups were $\mathrm{HF}$ and AF. Myocardial infarction was diagnosed by the presence of 2 out of 3 clinical criteria: new diagnostic Qwaves on ECG, prolonged ischemic chest discomfort, and elevation of serum biomarkers of myocardial necrosis. CHD death was established upon review of all available records, if the cause of death was probably CHD and no other cause could be ascribed.

Atherothrombotic brain infarction was defined as a nonembolic acute-onset focal neurological deficit of vascular etiology that persisted for more than 24 hours or an ischemic infarct was documented at autopsy.

History of interim hospitalizations and symptoms of HF were obtained at each clinic examination; outside medical records were evaluated for participants who did not attend an examination. Three physicians reviewed all suspected interim events using Framingham Heart Study clinic notes, external physician reports and hospitalization records. HF was diagnosed when at least two major criteria were present, or one major and two minor criteria. Major criteria were paroxysmal nocturnal dyspnea, pulmonary rales, distended jugular veins, enlarging heart size 
on chest radiography, acute pulmonary edema, hepatojugular reflux, third heart sound, jugular venous pressure of $16 \mathrm{~cm}$ or greater, weight loss of $4.5 \mathrm{~kg}$ or greater in response to diuresis, pulmonary edema, visceral congestion, or cardiomegaly on autopsy. Minor criteria counted only if not attributed to another disease. Minor criteria were bilateral ankle edema, nocturnal cough, shortness of breath on ordinary exertion, hepatomegaly, pleural effusion, vital capacity decreased by one third from previous maximum, and heart rate $\geq 120$ beats $/ \mathrm{min}$.

AF was diagnosed when, upon review by a study cardiologist, AF or atrial flutter was present on an ECG obtained from a routine Framingham clinic examination or from a hospital or physician record. HF was defined on the basis of review of medical records and the finding of concurrent presence of two major or one major plus two minor criteria [19].

\section{Genotyping methods}

The accompanying Overview [20] provides details of the genotyping methods used in this investigation. The Affymetrix $100 \mathrm{~K}$ chip with 112,990 autosomal SNPs was used to genotype individual participant DNA on the Framingham Heart Study family plate set. SNPs were excluded for minor allele frequency $<0.1(\mathrm{n}=38062)$; call rate $<0.8(\mathrm{n}=2346)$; Hardy Weinberg equilibrium $\mathrm{p}$ value $<0.001(\mathrm{n}=1595)$. After these exclusions, 70,987 SNPs were available for analysis.

\section{Statistical methods}

Proportional-hazards models were used to analyze time to each endpoint, stratified by cohort, using covariate values obtained at enrollment. Models were adjusted for (i) sex and age, or (ii) sex, age and multiple covariates. For CVD and CHD, covariates included smoking, diabetes, systolic BP, anti-hypertensive treatment and total cholesterol; for HF, covariates were smoking, diabetes, systolic $\mathrm{BP}$, anti-hypertensive treatment and body mass index; for $\mathrm{AF}$, covariates were diabetes, systolic $\mathrm{BP}$, anti-hypertensive therapy and valve disease. Deviance residuals estimated from each model were standardized (mean 0 , variance 1 ) to form the phenotypes analyzed with genetic models. For genotype-phenotype association analyses, we assumed an additive-allele model of inheritance and we conducted association tests using regression models with generalized estimating equations (GEE), as well as family-based association testing using FBAT. Due to relatively small numbers of outcome events and non-normality of the deviance residuals, we decided a priori not to perform linkage analysis on outcomes residuals. The distribution of observed $p$ values for the four CVD outcomes was compared to that which would be expected under the null hypothesis of no genetic associations with outcomes.

\section{Candidate gene analyses}

GEE and FBAT additive genetic effect models also were run for SNPs in or near candidate genes for each of the CVD outcomes. Candidate genes were selected after separate literature searches for each outcome. All SNPs across the interval extending from $200 \mathrm{~Kb}$ proximal to the start to $200 \mathrm{~kb}$ beyond the end of each gene were eligible if the minor allele frequency was $\geq 0.1$, the genotype call rate was $\geq 0.8$, and the Hardy-Weinberg equilibrium $p$ value was $\geq 0.001$.

\section{Results}

Four primary phenotypes were analyzed: major atherosclerotic CVD $(\mathrm{n}=142)$, major CHD $(\mathrm{n}=118), \operatorname{HF}(\mathrm{n}=$ $73)$, and AF ( $\mathrm{n}=151)$. Covariates for each outcome are listed in Table 1. In this sample, deviance residuals from multivariable models generally had low heritability: HF, $0.023(\mathrm{SE}=0.054)$; Major CVD, $0.036(\mathrm{SE}=0.058)$, Major CHD, $0.085(\mathrm{SE}=0.061)$; and $\mathrm{AF}, 0.135(\mathrm{SE}=0.058)$.

GEE additive genetic models yielded six associations with $\mathrm{p}$ values $<10^{-5}$ and another 31 with $\mathrm{p}$ values $<10^{-4}$ (see Table 2a for best 25). The lowest p-values for each CVD phenotype were as follows: major CVD, rs499818, $\mathrm{p}=6.6$ $\times 10^{-6}$; major CHD, rs2549513, $\mathrm{p}=9.7 \times 10^{-6} ; \mathrm{AF}$, rs958546, $\mathrm{p}=4.8 \times 10^{-6} ; \mathrm{HF}$ : rs740363, $\mathrm{p}=8.8 \times 10^{-6}$. Of note, rs10501920 in CNTN5 was associated with AF ( $\mathrm{p}=$ $\left.9.4 \times 10^{-6}\right)$ and HF $\left(\mathrm{p}=1.2 \times 10^{-4}\right)$. Three SNPs near PHACTR1 were associated with major CVD (rs499818, rs 1512411, rs507369; lowest $\mathrm{p}=6.6 \times 10^{-6}$ ) and one of these was associated with major CHD (rs1512411;

Table I: Phenotype definitions

\begin{tabular}{|c|c|c|c|c|}
\hline Phenotype & Definition & Number of individuals & Number with event & Adjustment* \\
\hline Major CVD & $\begin{array}{l}\text { Myocardial infarction, coronary } \\
\text { insufficiency, CHD death, or } \\
\text { atherothrombotic stroke }\end{array}$ & 1345 & 142 & $\begin{array}{l}\text { Age, sex; Multivariable: Age, sex, smoking, diabetes, } \\
\text { systolic BP, anti-hypertensive therapy, total } \\
\text { cholesterol }\end{array}$ \\
\hline Major CHD & $\begin{array}{l}\text { Myocardial infarction, coronary } \\
\text { insufficiency, or CHD death }\end{array}$ & 1345 & 118 & Same as Major CVD \\
\hline Heart failure & $\begin{array}{l}\text { Heart failure, hospitalized or non- } \\
\text { hospitalized }\end{array}$ & 1345 & 73 & $\begin{array}{l}\text { Same as Major CVD except BMI added, total } \\
\text { cholesterol removed }\end{array}$ \\
\hline Atrial fibrillation & Atrial fibrillation or atrial flutter on ECG & $|34|$ & $15 \mid$ & $\begin{array}{l}\text { Age, sex; Multivariable: Age, sex, diabetes, systolic } \\
\text { BP, anti-hypertensive therapy, valve disease }\end{array}$ \\
\hline
\end{tabular}

* Covariates in cohort-stratified proportional-hazards models for time to event 
Table 2: Additive Genetic Model - ordered by GEE (2a) and FBAT (2b) p-value Results

\begin{tabular}{|c|c|c|c|c|c|c|}
\hline Phenotype & SNP & Chromosome & Position & GEE $P$ value & FBAT $P$ value & Gene \\
\hline \multicolumn{7}{|c|}{ 2a. Results ordered by GEE p-value results } \\
\hline $\mathrm{AF}$ & rs958546 & 13 & $45,731,7 \mid 8$ & 4.78E-06 & 0.104 & \\
\hline Major CVD & rs499818 & 6 & $13,440,446$ & 6.64E-06 & 0.17 & \\
\hline$A F$ & rs4776472 & 15 & $67,793,927$ & 7.87E-06 & 0.042 & \\
\hline $\mathrm{HF}$ & rs740363 & 10 & I I8,565,596 & 8.82E-06 & 0.065 & KIAA/598 \\
\hline $\mathrm{AF}$ & rs10501920 & 11 & $98,998,383$ & $9.40 \mathrm{E}-06$ & 0.448 & CNTN5 \\
\hline Major CHD & rs2549513 & 16 & $78,108,228$ & $9.65 \mathrm{E}-06$ & 0.106 & \\
\hline$A F$ & rs10507539 & 13 & $45,732,707$ & I.05E-05 & 0.02 & \\
\hline Major CVD & rsI5I24II & 6 & $13,439,076$ & I.55E-05 & 0.366 & PHACTRI, TBCID7 \\
\hline Major CVD & rs105II701 & 9 & $22,102,599$ & I.67E-05 & 0.132 & \\
\hline Major CVD & rs|5565I6 & 9 & $22,090,176$ & I.86E-05 & 0.071 & \\
\hline Major CVD & rs|53737| & 9 & $22,089,568$ & I.87E-05 & 0.068 & \\
\hline Major CHD & rs10497726 & 2 & $192,876,826$ & I.98E-05 & 0.046 & TMEFF2 \\
\hline Major CHD & rs2962994 & 15 & $55,129,991$ & I.98E-05 & 0.279 & TCFI2 \\
\hline Major CHD & rs99765I & 17 & $61,344,845$ & $2.28 \mathrm{E}-05$ & 0.547 & MGC33887 \\
\hline Major CVD & rs2148079 & 13 & $109,989,4 \mid 4$ & 2.33E-05 & 0.026 & $R A B 20$ \\
\hline $\mathrm{AF}$ & rs10501918 & 11 & $98,971,412$ & $2.40 \mathrm{E}-05$ & 0.093 & CNTN5 \\
\hline $\mathrm{HF}$ & rs105II633 & 9 & $17,151,527$ & 2.59E-05 & 0.044 & C9orf39 \\
\hline Major CHD & rs7836535 & 8 & $96,774,748$ & 2.63E-05 & 0.003 & \\
\hline Major CHD & rs 1820996 & 15 & $55,120,501$ & $2.83 E-05$ & 0.218 & $T C F / 2$ \\
\hline Major CHD & $r s 213168$ & 15 & $55,028,949$ & 3.09E-05 & 0.278 & TCFI2 \\
\hline Major CHD & rs997652 & 17 & $61,344,827$ & 3.22E-05 & 0.613 & MGC33887 \\
\hline$A F$ & rs4590838 & 11 & $97,372,875$ & 4.03E-05 & 0.248 & \\
\hline Major CHD & rs10516882 & 4 & $92,265,754$ & 4.33E-05 & 0.858 & \\
\hline Major CVD & rs 1742083 & 14 & $90,256,423$ & 5.23E-05 & 0.138 & TTC7B \\
\hline Major CVD & rs507369 & 6 & $13,440,039$ & 6.23E-05 & 0.137 & PHACTRI, TBCID7 \\
\hline
\end{tabular}

2b. Results Ordered by FBAT

\begin{tabular}{|c|c|c|c|c|c|c|}
\hline Major CHD & rsl0505879 & 12 & $22,539,123$ & 0.058 & 3.06E-05 & KIAA0528 \\
\hline Major CVD & rs39312 & 7 & I I 6,548,736 & 0.138 & 4.37E-05 & WNT2 \\
\hline $\mathrm{AF}$ & rsl051131। & 3 & I I3,538,529 & 0.003 & 4.45E-05 & $C D 200$ \\
\hline$A F$ & rs|427828 & 12 & $88,264,967$ & 0.018 & 4.58E-05 & DUSP6 \\
\hline $\mathrm{HF}$ & rsl05I5869 & 5 & $163,444,804$ & 0.029 & 4.72E-05 & \\
\hline$A F$ & rs|75|382 & 14 & $67,762,403$ & 0.138 & 5.I4E-05 & RAD5 ILI \\
\hline$A F$ & rs 1314913 & 14 & $67,769,347$ & 0.126 & 5.53E-05 & RAD5 ILI \\
\hline$A F$ & rs262467 & 6 & $120,497,469$ & 0.117 & 6.39E-05 & \\
\hline$A F$ & rs4I2253 & 4 & $31,119,019$ & 0.086 & 6.55E-05 & \\
\hline Major CVD & rs39317 & 7 & $\mathrm{I} 16,560,255$ & 0.219 & 6.72E-05 & WNT2, ASZI \\
\hline Major CVD & rs9886209 & 7 & I I6,599,175 & 0.594 & 6.95E-05 & $A S Z I$ \\
\hline Major CVD & rs 10493900 & I & $98,357,234$ & 0.801 & 7. I OE-05 & \\
\hline $\mathrm{AF}$ & rsI298340 & 14 & $67,747,245$ & 0.275 & 7.40E-05 & RAD5 ILI \\
\hline Major CVD & rs2452503 & 10 & $60,686,639$ & 0.384 & 9.94E-05 & FAM I $3 \mathrm{Cl}$ \\
\hline $\mathrm{AF}$ & rs324735 & 4 & $77,062,193$ & 0.018 & 9.98E-05 & \\
\hline Major CHD & rs580069 & II & $121,794,555$ & 0.074 & I.24E-04 & \\
\hline $\mathrm{AF}$ & rsl 604355 & I & $187,190,664$ & 0.294 & I.29E-04 & FAM5C \\
\hline Major CHD & rs559453 & II & $121,794,482$ & 0.073 & I.32E-04 & \\
\hline Major CHD & rs95। 442 & 15 & $31,705,234$ & 0.003 & I.35E-04 & RYR3 \\
\hline $\mathrm{HF}$ & rs I I 76486 & 10 & $132,3 \mid 5,529$ & 0.165 & I .49E-04 & \\
\hline$A F$ & rs2421954 & 2 & $63,665,926$ & 0.003 & I.5 I E-04 & LOC5 I 057 \\
\hline $\mathrm{HF}$ & rs9313999 & 5 & $163,444,569$ & 0.015 & I.55E-04 & \\
\hline$A F$ & rs7676376 & 4 & $158,199,764$ & 0.282 & I.72E-04 & PDGFC \\
\hline Major CHD & rsl050II27 & II & $33,698,233$ & 0.251 & I.78E-04 & CD59 \\
\hline $\mathbf{A F}$ & rsII63397 & 3 & I 10,400,929 & 0.002 & I.78E-04 & \\
\hline
\end{tabular}


Table 3: Distribution of Observed and Expected $P$ Values from GEE models

\begin{tabular}{|c|c|c|c|c|}
\hline$P$ value group & Frequency & Percent & Expected* & Ratio** \\
\hline $0.10 \leq p$ & 254,464 & 89.6164 & $90.000 \%$ & 1.00 \\
\hline $0.01 \leq p<0.10$ & 26,218 & 9.2334 & $9.000 \%$ & 1.03 \\
\hline $0.001 \leq p<0.01$ & 2,892 & 1.0185 & $0.900 \%$ & 1.13 \\
\hline $0.0001 \leq p<0.001$ & 337 & 0.1187 & $0.090 \%$ & 1.32 \\
\hline $0.00001 \leq p<0.0001$ & 31 & 0.0109 & $0.009 \%$ & 1.21 \\
\hline$p<0.00001$ & 6 & 0.0021 & $0.001 \%$ & 2.11 \\
\hline
\end{tabular}

*Expected under uniform distribution. **Ratio of observed to expected.

$\left.\mathrm{p}=6.3 \times 10^{-5}\right)$. Among GEE results for HF was rs939698 $\left(\mathrm{p}=3.6 \times 10^{-4}\right)$ in $R Y R 2$, which has been implicated in arrhythmogenic right ventricular dysplasia/cardiomyopathy [21], a rare familiar cardiomyopathy.

Results of FBAT are provided in Table $2 \mathrm{~b}$. The lowest p values for each phenotype were: major CVD, rs39312 in WNT2, $\mathrm{p}=4.4 \times 10^{-5}$; major CHD, rs10505879, $\mathrm{p}=3.1 \times$ $10^{-5}$; $\mathrm{AF}, \mathrm{rs} 10511311$ in CD200, $\mathrm{p}=4.5 \times 10^{-5}$; and $\mathrm{HF}$, rs10515869, $4.72 \times 10^{-5}$.

The distribution of observed GEE $\mathrm{p}$ values is presented in Table 3. Note that the ratio of observed to expected numbers is inflated only at very low p values.

Association results for 408 SNPs in 46 candidate genes (Table 4) revealed suggestive evidence for major $\mathrm{CHD}$ events for ALOX5AP (23 SNPs, 7 with $\mathrm{p}<0.05$ by GEE or FBAT), GJA4 (14 SNPs, 6 with p < 0.05), MEF2A (5 SNPs, 2 with $\mathrm{p}<0.05)$, and PCSK9 ( 11 SNPs, 3 with $\mathrm{p}<0.05$ ). For HF, 4 SNPs in PLN and 2 each in ADRB2 and TPM1 had $\mathrm{p}$ values $<0.05$. There was little evidence of association of AF with SNPs in specified candidate genes. Overall, 538 candidate-SNP association tests were carried out because there were 130 SNPs common to both major CHD and major CVD. Results with GEE $\mathrm{p}<0.05$ were obtained for 28 tests (5.2\%) and p $<0.01$ for 5 tests $(0.9 \%)$, similar to the overall distribution in Table 3. Lack of consistency between GEE and FBAT results may be due to lower power of FBAT compared with GEE tests.

Additionally, we examined all association results for major CHD and major CVD in the region of chromosome 9 that was recently reported to be associated with MI and CHD $[22,23]$, We found that 7 SNPs in a $76 \mathrm{~Kb}$ region had $\mathrm{p}<10^{-5}$ for one or both outcomes.

\section{Discussion}

Cardiovascular disease is the leading cause of death in industrialized countries and will soon be the leading cause of death in the developing world [24]. Genomewide association studies provide an opportunity to extend our understanding of CVD pathogenesis and improve public health. The identification of novel genes and path- ways that play a causal role in CVD is an essential objective for the development of new therapies for the prevention and treatment of CVD. Finding genetic associations with CVD risk that are robust across multiple studies will aid in the personalization of medicine by identifying high risk individuals who can be targeted for early and aggressive preventive care.

We provide results of genome-wide association for 4 CVD outcomes of great public health impact: major CVD, major CHD, AF, and HF. No associations attained genome-wide significance $\left[4.4 \times 10^{-8}=0.05 /(70,987 \mathrm{SNPs}\right.$ $\times 4$ major traits $\times 2$ adjustment levels $\times 2$ association models)] in our analyses using GEE or FBAT additive genetic models. With dramatic declines in the cost of high throughput genotyping, selective genotyping of SNPs with suggestive evidence of association can be considered. Two-stage approaches - genome-wide association followed by selective genotyping - have been adopted as a practical and efficient strategy for pursuing initial genome-wide results $[25,26]$.

Results of GEE and FBAT associations pointed to few candidate genes of obvious interest for any CVD outcomes. One intriguing result was the association of RYR2 (rs939698, p = $3.6 \times 10^{-4}$ ) with HF. The ryanodine receptor has been implicated in arrhythmogenic right ventricular dysplasia/cardiomyopathy [21,27], a rare familial cardiomyopathy.

The lowest $\mathrm{p}$ values we identified may be purely by chance. The number of events (maximum of 142 for major CVD) was small to detect association, but would be sufficient to detect a SNP with high minor allele frequency in linkage disequilibrium with a causal variant that contributed high risk. This was the case for a genome-wide association study of age-related macular degeneration only 96 cases and 50 controls were sufficient to identify genome-wide association with complement factor $\mathrm{H}$ [28]. Sometimes multiple SNPs in the same chromosomal region had low GEE p values for a trait; for example, Table 2a has SNP clusters on chromosomes 6, 9, 11, 13, 15 and 17. Linkage disequilibrium exists for those clustered SNPs (typically, pair-wise $\mathrm{r}^{2}$ above 0.80 ) and it is uncertain 
Table 4: Association Results for Pre-Specified Candidate Genes

\begin{tabular}{|c|c|c|c|c|c|}
\hline Candidate gene & Total number of SNPs* & SNPs with $p$ value $<0.05$ & Phenotype & GEE $p$ value & FBAT $p$ value \\
\hline \multicolumn{6}{|c|}{ Major CVD/Major CHD } \\
\hline ALOX5 & 5 & 0 & & & \\
\hline \multirow[t]{8}{*}{ ALOX5AP } & 23 & rs7983I38 & Major CHD & 0.011 & 0.373 \\
\hline & & rs2985I83 & Major CHD & 0.014 & 0.455 \\
\hline & & rs7984952 & Major CHD & 0.015 & 0.266 \\
\hline & & rsII7395 & Major CHD & 0.016 & 0.568 \\
\hline & & rs4603405 & Major CHD & 0.018 & 0.257 \\
\hline & & rs10507391 & Major CHD & 0.028 & 0.660 \\
\hline & & rs 10507391 & Major CVD & 0.043 & 0.878 \\
\hline & & rs7995384 & Major CHD & 0.049 & 0.967 \\
\hline \multirow[t]{10}{*}{ GJA4 } & 14 & rs618675 & Major CHD & 0.004 & 0.169 \\
\hline & & rs10489658 & Major CHD & 0.004 & 0.145 \\
\hline & & rs618675 & Major CVD & 0.009 & 0.464 \\
\hline & & rs 10493062 & Major CHD & 0.011 & 0.051 \\
\hline & & rs768586 & Major CHD & 0.016 & 0.135 \\
\hline & & rs 10489658 & Major CVD & 0.025 & 0.237 \\
\hline & & rs 10489656 & Major CHD & 0.520 & 0.030 \\
\hline & & rs 10489656 & Major CVD & 0.538 & 0.044 \\
\hline & & rs2093185 & Major CVD & 0.547 & 0.019 \\
\hline & & rs6686484 & Major CHD & 1.000 & 0.031 \\
\hline LGALS2 & I & 0 & & & \\
\hline LTA & 2 & 0 & & & \\
\hline LTA4H & 22 & rs 10492225 & Major CHD & 0.013 & 0.080 \\
\hline \multirow[t]{4}{*}{ MEF2A } & 5 & rs2033546 & Major CVD & 0.004 & 0.006 \\
\hline & & rs2863274 & Major CVD & 0.006 & 0.006 \\
\hline & & rs2033546 & Major CHD & 0.016 & 0.013 \\
\hline & & rs2863274 & Major CHD & 0.062 & 0.021 \\
\hline \multirow[t]{3}{*}{ MMP3 } & 17 & rs2096767 & Major CVD & 0.028 & 0.506 \\
\hline & & rs2096767 & Major CHD & 0.032 & 0.610 \\
\hline & & rs566125 & Major CVD & 0.042 & 0.079 \\
\hline SERPINEI & 2 & 0 & & & \\
\hline \multirow[t]{6}{*}{ PCSK9 } & 11 & rs2114580 & Major CHD & 0.010 & 0.075 \\
\hline & & rs2114580 & Major CVD & 0.026 & 0.057 \\
\hline & & rs23I795I & Major CVD & 0.076 & 0.002 \\
\hline & & rs23I795I & Major CHD & 0.077 & 0.002 \\
\hline & & rs23I7948 & Major CHD & 0.478 & 0.029 \\
\hline & & rs2317948 & Major CVD & 0.584 & 0.026 \\
\hline \multirow[t]{2}{*}{ THBS2 } & 7 & rs911839 & Major CVD & 0.192 & 0.035 \\
\hline & & rs911839 & Major CHD & 0.255 & 0.032 \\
\hline THBS4 & 16 & rs264986 & Major CHD & 0.443 & 0.048 \\
\hline VAMP8 & 5 & 0 & & & \\
\hline
\end{tabular}

\begin{tabular}{|c|c|c|c|c|}
\hline \multicolumn{5}{|c|}{ Atrial fibrillation } \\
\hline$A C E$ & 3 & 0 & & \\
\hline$A G T$ & 13 & rs758216 & 0.041 & 0.204 \\
\hline GJA5 & 13 & 0 & & \\
\hline KCNE2 & 14 & 0 & & \\
\hline $\mathrm{KCNH} 2$ & 6 & 0 & & \\
\hline$K C N / 2$ & 23 & rs 10512574 & 0.140 & 0.041 \\
\hline KCNQI & 5 & rs 10488674 & 0.136 & 0.046 \\
\hline \multirow[t]{2}{*}{ KCNEI } & 20 & rs7277304 & 0.745 & 0.047 \\
\hline & & rs930555I & 0.119 & 0.018 \\
\hline
\end{tabular}

Heart failure

\begin{tabular}{lllr}
\hline$A B C C 9$ & 8 & 0 & \\
$A C T C$ & 15 & rs752876 & 0.065
\end{tabular}


Table 4: Association Results for Pre-Specified Candidate Genes (Continued)

\begin{tabular}{|c|c|c|c|c|}
\hline ADRBI & 12 & 0 & & \\
\hline \multirow[t]{2}{*}{ ADRB2 } & 18 & rs40949 & 0.545 & 0.025 \\
\hline & & rsl8502I & 0.947 & 0.040 \\
\hline$A D R B K I$ & 0 & - & & \\
\hline ATP2A2 & 3 & 0 & & \\
\hline CALML3 & 2 & 0 & & \\
\hline CTFI & 0 & - & & \\
\hline$D E S$ & 2 & 0 & & \\
\hline$D S P$ & 15 & rs 10484326 & 0.671 & 0.029 \\
\hline LDB3 & 0 & - & & \\
\hline LMNA & 5 & 0 & & \\
\hline MYBPC3 & 4 & 0 & & \\
\hline MYH6 & I & 0 & & \\
\hline MYH7 & 2 & 0 & & \\
\hline MYL2 & 3 & 0 & & \\
\hline MYL3 & I & 0 & & \\
\hline \multirow[t]{4}{*}{ PLN } & 16 & rs3951042 & 0.025 & 0.083 \\
\hline & & rs724868 & 0.055 & 0.039 \\
\hline & & rs9320660 & 0.063 & 0.034 \\
\hline & & rs 10484286 & 0.074 & 0.043 \\
\hline$S G C D$ & 37 & 0 & & \\
\hline TNNCI & 4 & rsll334I5 & 0.040 & 0.131 \\
\hline TNNI3 & I & 0 & & \\
\hline TNNT2 & 9 & rs832177 & 0.015 & 0.164 \\
\hline \multirow[t]{2}{*}{ TPMI } & 7 & rs 10519186 & 0.011 & 0.085 \\
\hline & & rs 902027 & 0.152 & 0.011 \\
\hline TTN & 13 & rs I049752I & 0.705 & 0.030 \\
\hline$V C L$ & 3 & 0 & & \\
\hline
\end{tabular}

*Includes all SNPs within $200 \mathrm{~kb}$ upstream of start to $200 \mathrm{~kb}$ downstream of end of gene, with genotype call rate $\geq 0.8$; minor allele frequency $\geq 0.1$; HWE $p \geq 0.001$.

Data are sorted by GEE additive genetic effects model with FBAT results provided alongside.

whether the concordant results represent statistically correlated chance findings or indicate regions of heightened interest.

Candidate gene results for the 4 CVD outcomes provided suggestive confirmation of prior associations reported for ALOX5AP ( 23 SNPs, 7 with $\mathrm{p}<0.05$ by GEE or FBAT), GJA4 (14 SNPs, 6 with $\mathrm{p}<0.05$ ), MEF2A (5 SNPs, 2 with $\mathrm{p}<0.05$ ), and PCSK9 ( 11 SNPs, 3 with $\mathrm{p}<0.05$ ) in relation to CHD risk. In contrast, candidate gene results for HF and AF provided little evidence of replication of previously reported associations. Null results of these associations may be due in part to poor coverage of the candidates by the SNPs on the $100 \mathrm{~K}$ chip and the modest number of events available for analysis. Our results can be compared with other genome-wide associations of similar phenotypes. We observed strong association of major CVD with 3 SNPs in the region of chromosome 9 that was recently reported to be associated with $\mathrm{MI}$ and $\mathrm{CHD}$ in multiple samples $[22,23]$. This provides convincing evidence that, despite modest numbers of events, we were able to identify true associations.

This investigation has several limitations. This study used CVD cases that were identified through careful surveil- lance of a community-based sample with multigenerational participation. Recruitment of original and offspring cohort participants began long before DNA collection, which occurred in recent years. Thus, most CVD cases were prevalent at the time of DNA collection. For CVD outcomes (such as these) with substantial mortality risk, a survival bias may have been introduced by this study design; individuals with early CVD events had to survive and attend a later clinic examination at which DNA was collected. Another limitation is the modest number of events included in analyses, in particular for HF, where only 73 events were available for analysis. For continuous traits, we had 78\% power to detect a SNP with QTL heritability of $1 \%$ at significance level $10^{-3}$, and at significance level $10^{-6}$ we had $84 \%$ power for QTL heritability $2 \%$ [20]. In the setting of a limited number of outcome events, those are large effect sizes. The negative results of candidate gene analyses may underestimate associations for genes that are incompletely covered by the SNPs used in this investigation. Lastly, a large proportion of the results are likely to be due to chance. Replication studies are needed to determine which, if any, of the results we report are indicative of true associations of causal variants with disease outcomes. 
These association results for major CVD outcomes extend experience with genome-wide association studies. Replication studies are needed and will be used to guide future genotyping and resequencing efforts. Finding genetic variants associated with CVD may facilitate the identification of high risk patients and aid in identifying targeted future approaches to prevention and treatment of CVD.

\begin{abstract}
Abbreviations
$\mathrm{AF}=$ atrial fibrillation; $\mathrm{CHD}=$ coronary heart disease; $\mathrm{HF}$ = heart failure; $\mathrm{CVD}=$ cardiovascular disease; $\mathrm{FBAT}=$ family based association test; GEE = generalized estimating equation.
\end{abstract}

\section{Competing interests}

The authors declare that they have no competing interests.

\section{Authors' contributions}

MGL participated in study design, data collection, statistical analysis, interpretation of results, and manuscript preparation. LDA contributed to the design and analysis. EJB contributed to the design of analyses, acquisition and interpretation of data, provided critical manuscript revisions. LAC contributed to the design and analysis. RBD contributed to the design and analysis. CSF contributed to data acquisition and approved the final version of the manuscript. DRG contributed to project design and data acquisition. CYG participated in statistical analysis. NLHC contributed to the design and analysis. SJH participated in statistical analysis and manuscript preparation. JMM participated in acquisition of data, interpretation, revising \& approval of final manuscript. CNC participated in the analysis and interpretation of data and critical review of the manuscript. CJOD participated in the analysis and interpretation of data and critical review of the manuscript. SS participated in data collection, definition of phenotypes and review of the manuscript. RSV participated in data collection, interpretation of analyses and review of the manuscript. TJW contributed to data acquisition data, interpretation of data analysis, and revision of the manuscript for important intellectual content. PAW participated in data collection and project conception and design. DL contributed to project conception and design, interpretation of results, and drafting the manuscript.

All authors approved the final manuscript.

\section{Acknowledgements}

We acknowledge the Framingham Study participants. This work is supported by National Institute of Health/National Heart, Lung \& Blood Institute (NHLBI) Contract NOI-HC 25I95. A portion of the research was conducted using the Boston University Linux Cluster for Genetic Analysis (LinGA) funded by the NIH NCRR (National Center for Research Resources) Shared Instrumentation grant (ISIORRI63736-0IAI).
This article has been published as part of BMC Medical Genetics Volume 8 Supplement I, 2007: The Framingham Heart Study 100,000 single nucleotide polymorphisms resource. The full contents of the supplement are available online at http://www.biomedcentral.com/|47|-2350/8? issue=SI.

\section{References}

I. Rosamond W, Flegal K, Friday G, Furie K, Go A, Greenlund K, Haase N, Ho M, Howard V, Kissela B, Kittner S, Lloyd-jones D, McDermott M, Meigs J, Moy C, Nichol G, O'Donnell CJ, Roger V, Rumsfeld J, Sorlie P, Steinberger J, Thom T, Wasserthiel-Smoller S, Hong Y: . Heart disease and stroke statistics--2007 update: a report from the American Heart Association Statistics Committee and Stroke Statistics Subcommittee. Circulation 2007, II5:e69-el7I.

2. Lloyd-Jones DM, Larson MG, Beiser A, Levy D: Lifetime risk of developing coronary heart disease. Lancet 1999, 353:89-92.

3. Seshadri S, Beiser A, Kelly-Hayes M, Kase CS, Au R, Kannel WB, Wolf PA: The lifetime risk of stroke: estimates from the Framingham Study. Stroke 2006, 37:345-350.

4. Lloyd-Jones DM, Larson MG, Leip EP, Beiser A, D'Agostino RB, Kannel WB, Murabito JM, Vasan RS, Benjamin EJ, Levy D: Lifetime risk for developing congestive heart failure: the Framingham Heart Study. Circulation 2002, 106:3068-3072.

5. Lloyd-Jones DM, Wang TJ, Leip EP, Larson MG, Levy D, Vasan RS, D'Agostino RB, Massaro JM, Beiser A, Wolf PA, Benjamin E): Lifetime risk for development of atrial fibrillation: the Framingham Heart Study. Circulation 2004, I I 0: 1 042-1046.

6. Lloyd-Jones DM, Nam BH, D'Agostino RB Sr, Levy D, Murabito JM, Wang TJ, Wilson PW, O'Donnell CJ: Parental cardiovascular disease as a risk factor for cardiovascular disease in middleaged adults: a prospective study of parents and offspring. JAMA 2004, 29 I:2204-22II.

7. Lee DS, Pencina MJ, Benjamin EJ, Wang TJ, Levy D, O'Donnell CJ, Nam BH, Larson MG, D'Agostino RB, Vasan RS: Association of parental heart failure with risk of heart failure in offspring. $N$ Engl J Med 2006, 355: I 38-1 47.

8. Fox CS, Parise H, D'Agostino RB Sr, Lloyd-Jones DM, Vasan RS, Wang TJ, Levy D, Wolf PA, Benjamin EJ: Parental atrial fibrillation as a risk factor for atrial fibrillation in offspring. JAMA 2004, 29I:285I-2855.

9. McCarthy JJ, Parker A, Salem R, Moliterno DJ, Wang Q, Plow EF, Rao S, Shen G, Rogers WJ, Newby LK, Cannata R, Glatt K, Topol E): Large scale association analysis for identification of genes underlying premature coronary heart disease: cumulative perspective from analysis of I I I candidate genes. J Med Genet 2004, 41:334-34I.

10. Helgadottir A, Manolescu A, Thorleifsson G, Gretarsdottir S, Jonsdottir H, Thorsteinsdottir U, Samani NJ, Gudmundsson G, Grant SF, Thorgeirsson G, Sveinbjornsdottir S, Valdimarsson EM, Matthiasson SE, Johannsson H, Gudmundsdottir O, Gurney ME, Sainz J, Thorhallsdottir M, Andresdottir M, Frigge ML, Topol EJ, Kong A, Gudnason V, Hakonarson H, Gulcher JR, Stefansson K: The gene encoding 5lipoxygenase activating protein confers risk of myocardial infarction and stroke. Nat Genet 2004, 36:233-239.

II. Ozaki K, Inoue K, Sato H, lida A, Ohnishi Y, Sekine A, Sato H, Odashiro K, Nobuyoshi M, Hori M, Nakamura Y, Tanaka T: Functional variation in LGALS2 confers risk of myocardial infarction and regulates lymphotoxin-alpha secretion in vitro. Nature 2004, 429:72-75.

12. Wang L, Fan C, Topol SE, Topol EJ, Wang Q: Mutation of MEF2A in an inherited disorder with features of coronary artery disease. Science 2003, 302: I578-I58I.

13. Shiffman D, Ellis SG, Rowland CM, Malloy MJ, Luke MM, lakoubova OA, Pullinger CR, Cassano J, Aouizerat BE, Fenwick RG, Reitz RE, Catanese Jj, Leong DU, Zellner C, Sninsky JJ, Topol EJ, Devlin JJ, Kane JP: Identification of four gene variants associated with myocardial infarction. Am J Hum Genet 2005, 77:596-605.

14. Ahmad F, Seidman JG, Seidman CE: The genetic basis for cardiac remodeling. Annu Rev Genomics Hum Genet 2005, 6: 185-216.

15. Roberts R: Genomics and cardiac arrhythmias. J Am Coll Cardiol 2006, 47:9-21.

16. Dawber TR, Meadors GF, Moore FE Jr: Epidemiological approaches to heart disease: the Framingham Study. Am J Public Health Nations Health 1951, 41:279-28I. 
17. Kannel WB, Feinleib M, McNamara PM, Garrison RJ, Castelli WP: An investigation of coronary heart disease in families. The Framingham offspring study. Am J Epidemiol 1979, I 1 0:281-290.

18. Cupples LA, D'Agostino RB, Kiely D: The Framingham Heart Study, Section 35. An Epidemiological Investigation of Cardiovascular Disease. Survival Following Cardiovascular Events: 30 Year Follow-up Bethesda, MD: National Heart, Lung and Blood Institute; 1988.

19. McKee PA, Castelli WP, McNamara PM, Kannel WB: The natural history of congestive heart failure: the Framingham study. $N$ Engl J Med I 97I, 285: I 44I- I 446.

20. Cupples LA, Benjamin EJ, D'Agostino RB Sr, Demissie S, DeStefano AL, Dupuis J, Falls K, Fox CS, Gottlieb DJ, Govindaraju DR, HeardCosta N, Hwang SJ, Kathiresan S, Kiel DP, Larson MG, Laramie JM, Levy D, Lunetta KL, Mailman MD, Manning AK, Meigs JB, Murabito JM, Newton-Cheh C, O'Connor GT, O'Donnell C], Pandey MA, Seshadri S, Vasan RS, Wilk JB, Wolf PA, Yang Q, Atwood LD: The Framingham Heart Study I00K SNP genome-wide association study resource: Overview of 17 phenotype work group reports. BMC Med Genet 2007, 8(SuppI I):SI.

21. Nava A, Canciani B, Daliento L, Miraglia G, Buja G, Fasoli G, Martini $B$, Scognamiglio $R$, Thiene $G$ : Juvenile sudden death and effort ventricular tachycardias in a family with right ventricular cardiomyopathy. Int I Cardiol 1988, 21: I I I-126.

22. McPherson R, Pertsemlidis A, Kavaslar N, Stewart A, Roberts R, Cox DR, Hinds DA, Pennacchio LA, Tybjaerg-Hansen A, Folsom AR, Boerwinkle $\mathrm{E}$, Hobbs $\mathrm{HH}$, Cohen JC: A common allele on chromosome 9 associated with coronary heart disease. Science 2007, 316:1488-|49|.

23. Helgadottir A, Thorleifsson G, Manolescu A, Gretarsdottir S, Blondal $T$, Jonasdottir A, Jonasdottir A, Sigurdsson A, Baker A, Palsson A, Masson G, Gudbjartsson D, Magnusson KP, Andersen K, Levey Al, Backman VM, Matthiasdottir S, Jonsdottir T, Palsson S, Einarsdottir H, Gunnarsdottir S, Gylfason A, Vaccarino V, Hooper WC, Reilly MP, Granger CB, Austin H, Rader DJ, Shah SH, Quyyumi AA, Gulcher JR, Thorgeirsson G, Thorsteinsdottir U, Kong A, Stefansson K: A Common Variant on Chromosome 9p2 I Affects the Risk of Myocardial Infarction. Science 2007.

24. Murray CJ, Lopez AD: Alternative projections of mortality and disability by cause 1990-2020: Global Burden of Disease Study. Lancet 1997, 349: I498-1504.

25. Skol AD, Scott $L J$, Abecasis GR, Boehnke M: Joint analysis is more efficient than replication-based analysis for two-stage genome-wide association studies. Nat Genet 2006, 38:209-2I3.

26. Wang H, Thomas DC, Pe'er I, Stram DO: Optimal two-stage genotyping designs for genome-wide association scans. Genet Epidemiol 2006, 30:356-368.

27. Tiso N, Stephan DA, Nava A, Bagattin A, Devaney JM, Stanchi F, Larderet G, Brahmbhatt B, Brown K, Bauce B, Muriago M, Basso C, Thiene G, Danieli GA, Rampazzo A: Identification of mutations in the cardiac ryanodine receptor gene in families affected with arrhythmogenic right ventricular cardiomyopathy type 2 (ARVD2). Hum Mol Genet 200I, 10:189-194.

28. Klein RJ, Zeiss C, Chew EY, Tsai JY, Sackler RS, Haynes C, Henning AK, SanGiovanni JP, Mane SM, Mayne ST, Bracken MB, Ferris FL, Ott J, Barnstable C, Hoh J: Complement factor $\mathbf{H}$ polymorphism in age-related macular degeneration. Science 2005, 308:385-389.

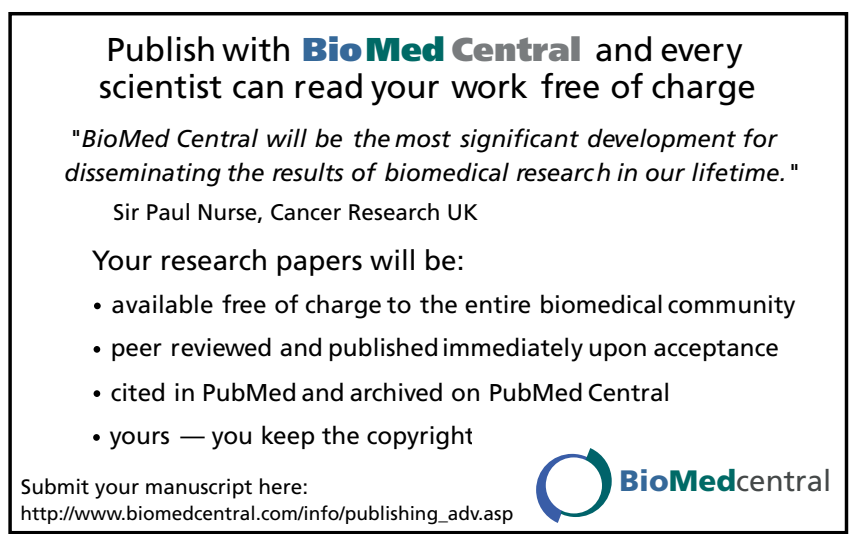

